\title{
Estimates of genetic parameters of growth traits of Nellore cattle in the Midwest region of Brazil
}

\author{
Estimativas de parâmetros genéticos em características de crescimento de bovinos da \\ raça Nelore na região centro-oeste do Brasil
}

\author{
ARAÚJO, Cláudio Vieira de ${ }^{1 *}$; LÔBO, Raysildo Barbosa ${ }^{2}$; FIGUEIREDO, Luis \\ Gustavo Girardi ${ }^{2}$; MOUSQUER, Cláudio Jonasson ${ }^{2}$; LAUREANO, Monyka Marianna \\ Massoloni ${ }^{1}$; BITTENCOURT, Thereza Cristina Borio dos Santos Calmon de ${ }^{4}$; \\ ARAÚJO, Simone Inoe ${ }^{1}$
}

\footnotetext{
${ }^{1}$ Universidade Federal de Mato Grosso, Instituto de Ciências Agrárias e Ambientais, Sinop, Mato Grosso, Brasil.

${ }^{2}$ Associação Nacional de Criadores e Pesquisadores, Ribeirão Preto, São Paulo, Brasil.

${ }^{3}$ Universidade Federal de Mato Grosso, Faculdade de Medicina Veterinária e Zootecnia,Cuiabá, Mato Grosso, Brasil.

${ }^{4}$ Universidade Federal da Bahia, Escola de Medicina Veterinária e Zootecnia, Departamento Produção Animal, Salvador, Bahia, Brasil.

*Endereço para correspondência: araujocv@bol.com.br
}

\section{SUMMARY}

Records of birth weight (BW) and weights standardized to 210 (W210); 365 (W365) and 550 (W550) of age in the Nellore breed were used to estimate variance components of genetic effects and predict genetic values of sires. The model included the fixed effects of contemporary group and cow age at calving as co-variable, and the additive and maternal genetic, permanent maternal environmental, and temporary environmental random effects. Estimates of means and standard deviations for BW, W210; W365 and W550 were $32.76 \pm$ $3.74 ; 184.30 \pm 29.02 ; 240.31 \pm 41.85$ and $322.12 \pm 60.77$, respectively. A significant additive genetic variability was detected for all weights. The permanent maternal environmental variance showed greater relevance on weaning weight, and it was practically inexistent after weaning. For the maternal genetic variance, the estimate for birth weight was more significant as compared with weaning weight. The estimated heritability values for BW, W210; W365 and W550 were $0.37 \pm 0.02 ; 0.36 \pm 0.03$; $031 \pm 0.01$ and $0.38 \pm 0.02$, respectively. Genetic correlations between birth weight and other weights were of low magnitude, with high values of weights at other ages. The use of sires of higher genetic value for total maternal effect makes it possible to use sires that are more positive for weaning weight and also for year and yearling weight.

Keywords: animal breeding, beef cattle, genetic evaluation

\section{RESUMO}

Registros de peso ao nascer (PN) e pesos padronizados para 210 (P210); 365 (P365) e 550 (P550) dias de idade na raça Nelore foram usados com o objetivo de estimar componentes de variância dos efeitos genéticos e predição de valores genéticos dos reprodutores. O modelo incluiu os efeitos fixos de grupo contemporâneo e idade da vaca ao parto, como covariável, além dos efeitos aleatórios genético aditivo direto e genético materno, de ambiente permanente materno e ambiente temporário. As estimativas das médias e desvios-padrão para PN; P210; P365 e P550 foram iguais a 32,76 $\pm 3,74$; $184,30 \pm 29,02 ; 240,31 \pm 41,85$ e $322,12 \pm$ 60,77 , respectivamente. Em todos os pesos, verificou-se considerável variabilidade genética aditiva. A variância de ambiente permanente materno apresentou maior relevância sobre o peso a desmama, sendo praticamente inexistente após o desmame. Para a variância genética 
materna, a estimativa para o peso ao nascer foi mais significativa quando comparada com o peso a desmama. Os valores estimados de herdabilidade para PN; P210; P365 e P550 foram iguais a $0,37 \pm 0,02 ; 0,36 \pm 0,03 ; 031 \pm$ 0,01 e $0,38 \pm 0,02$, respectivamente. As correlações genéticas entre peso ao nascer e outros pesos foram de baixa magnitude, com altos valores dos pesos em outras idades. $\mathrm{O}$ uso de reprodutores de maior valor genético para o efeito materno total permite utilizar reprodutores mais positivos para peso ao desmame e também para o ano e peso ao sobreano.

Palavras chaves: melhoramento animal, gado de corte, avaliação genética

\section{INTRODUCTION}

Despite being among the largest producers, the scenario being favorable, and the ever-growing demand for animal protein from both the internal and external markets, the Brazilian herd still needs improvement as it falls short of its true potential, especially in terms of productive and reproductive performances, which are paramount to decreasing the stocking rate, increasing the offtake rate, and providing a greater availability of animals for selection and production.

Hence, the key point in the animal selection process is the type of animal suited for the environmental conditions where it will be reared, thus establishing the selection criteria. The weight behavior of animals is of great interest to genetic breeding programs for beef cattle that utilize weight standardized at different ages as selection criteria, especially due to the ease of measurement and because they show a high and positive genetic correlation with several traits of economic interest. The Nellore breed, corresponding to the Ongole breed in India, showed its first records of importation to Brazil in the mid-twentieth century. Because of its adaptation in tropical environments, the Nellore breed is currently the largest cattle population in Brazil. As producer of meat, this breed has presented satisfactory economic performance values, partly as a result of actions related to genetic improvement programs.

Selection of animals for use as sires requires more precise estimates of (co)variance components for the selection criteria, as they allow for the right prediction of animals' genetic merit and the ranking of animals for each selection criterion.

The aim of this study was to estimate genetic parameters and predict breeding values of sires for birth weight and weights standardized to 205,365 and 550 days of age in Nellore cattle from the Midwest region of Brazil.

\section{MATERIALS AND METHODS}

Records of birth weight (BW) and weights standardized to 210 (W210); 365 (W365) and 550 (550) days of age, between 2001 and 2008, from 24,890 Nellore animals derived from 375 sires mating with 16,917 females, originated from five herds of the state of Mato Grosso (Midwest Brazil) participating in the Nellore Breeding Program Brazil's National Association of Nellore Breeders and Researchers, were used. Live-weight-control records were used to estimate genetic and environmental variance and to predict breeding values of sires.

In the model used for data analysis the months of birth were grouped into seasons 1 and 2, which correspond to the months of highest and lowest incidence of rainfall (from April to September and October to March), 
respectively. The fixed effects of herd, year and season of birth of the animals and animal sex were used to form the contemporary groups. Cow age at calving was considered a co-variable (linear and quadratic effects).

The animal model used to obtain components of variance and then to predict breeding values of sires, considering the birth weights and standardized weights to weaning at 210 days of age, was represented as $\mathbf{y}=\mathrm{X} \boldsymbol{\beta}$ $+Z_{1} \mathbf{a}+Z_{2} \mathbf{a m}+Z_{3} \mathbf{p m}+\mathbf{e}$, where $\mathbf{y}$ is a vector of observations of the traits; $X$ is an incidence matrix of levels of fixed effects; $\boldsymbol{\beta}$ is a vector of solutions of the fixed effects of group of contemporary and linear and quadratic effects of age at calving of the females, as covariate; $Z_{1}$ is an incidence matrix of direct additive genetic values; $\mathbf{a}$ is a vector of solutions of the direct additive genetic values of animals; $Z_{2}$ is an incidence matrix for maternal additive genetic values; am is a vector of solutions for additive maternal genetic; $Z_{3}$ is an incidence matrix for maternal permanent environmental effect; $\mathbf{p m}$ is a vector of values of maternal permanent environmental effect; and $\mathbf{e}$ is a vector of residuals of the same dimension of $\mathbf{y}$. For analysis of standardized weights at 365 and 550 days of age, the same model was used, but the maternal genetic effect was discarded.

The assumptions about the distribution of vectors $\mathrm{y}, \mathrm{a}$, and e are described as $\mathrm{E}(\mathrm{y})=X \beta$ and $\mathrm{V}(\mathrm{y})=\mathrm{Z}_{1} \mathrm{GZ}_{1}{ }^{\prime}+\mathrm{Z}_{2} \mathrm{MZ}_{2}{ }^{\prime}+$ $\mathrm{Z}_{3} \mathrm{PZ} \mathrm{Z}_{3}{ }^{\prime}+\mathrm{R}$, where $\mathrm{G}=\mathrm{A} \otimes \mathrm{G}_{0}, \mathrm{M}=\mathrm{A} \otimes$ $\mathrm{M}_{0}, \mathrm{P}=\mathrm{I} \otimes \mathrm{P}_{0}$ and $\mathrm{R}=\mathrm{I} \otimes \mathrm{R}_{0}$, where $\mathrm{A}$ is the numerators of the relationship matrix, of order equal to the number of individuals; $\mathrm{G}_{0}, \mathrm{M}_{0}, \mathrm{P}_{0}$ and $\mathrm{R}_{0}$ are the matrices of (co)variances are additive direct, additive maternal, maternal permanent environmental, and temporary environmental effects, respectively.
The direct additive genetic and maternal additive effects were considered correlated. To estimate variance components and predict breeding values, the Restricted Maximum Likelihood method was adopted.

After obtaining the breeding values of sires with offspring, a sample containing $10 \%$ of the best sires classified based on the total maternal effect was selected, and Spearman's correlation was applied to evaluate the ranking of breeding values of sires selected for improved maternal ability and its effects on other selection criteria.

The numerator relationship matrix (NRM), utilized in the analyses, was obtained from a pedigree file containing 50,540 animals. The data were edited on the Statistical Analysis System (SAS Institute, 2010) software aiming to use structure data that were coherent with traits of the breed so as to avoid the presence of outliers resulting from errors in data collection. Variance components, genetic parameters, and breeding values were obtained WOMBAT (MEYER, 2007) computer program.

\section{RESULTS AND DISCUSSION}

Number of observations $(\mathrm{N})$, estimates of means and standard deviations for BW, W210, W365 and W550 were equal to $(\mathrm{N}=17,889) 32.76 \pm 3.74 ;(\mathrm{N}$ $=21,448) 184.30 \pm 29.02 ;(\mathrm{N}=15,249)$ and $240.31 \pm 41.85(\mathrm{~N}=8867) 322.12$ \pm 60.77 , respectively.

The described values are consistent with the breed's pattern and similar to data described in the literature (BOLIGON et al., 2010), indicating that the average performance of weight development in the Nellore breed in the herds of Mato Grosso State is similar to the 
performance of other herds of the same breed in other states.

For all body weights, there was considerable additive genetic variability (Table 1), which can be used with efficiency in animal breeding programs, especially regarding birth weight, on which there selection neither for nor against is interesting. The variance in maternal permanent environmental effect showed greater relevance on weaning weight, though it was practically nonexistent at birth and postweaning weights. Similar results were observed by Mucari and Oliveira (2003) and Dias et al. (2005). For the maternal genetic variance, estimates on the birth weight were more significant when compared with weaning weight. However, the estimated values were well below those observed for the direct additive genetic variance.

Table 1. Direct additive genetic (Va), maternal additive genetic (Vma), maternal permanent environmental ( Vmp) and temporary environmental $(\mathrm{Ve})$ variance components for birth (BW), weaning (W210), year (W365) and yearling (W550) weights

\begin{tabular}{lcccc}
\hline Variance component & BW & W210 & W365 & W550 \\
\hline Va & 3.13 & 137.73 & 233.34 & 416.36 \\
Vma & 0.92 & 20.98 & - & - \\
Vmp & 0.29 & 49.31 & 14.25 & 3.62 \\
Ve & 4.1 & 175 & 503.62 & 681.43 \\
\hline
\end{tabular}

The effect of the higher additive genetic variability present in the sample was reflected in moderate estimates of heritability for all ages (Table 2), indicating good response of genetic gain expected by the effect of selection for these weights. It also demonstrates the important contribution of the candidate's own information (mass selection). Special attention should be given to the birth weight, avoiding the use of sires with high expected differences in the offspring and consequently the excessive increase in birth weight and increased incidence of dystocia.

The heritability estimate for birth weight was similar to that obtained by Mello et al. (2006), but the authors found higher estimates for weights at weaning and year, which were 0.48 and 0.63 , respectively. Direct heritability estimates for birth weight, weaning weight, and yearling weight obtained by Boligon et al. (2009) were 0.25; 0.33;
0.34 , respectively, similarly to those obtained in this study.

Maternal heritability estimates were low, indicating low accuracy and efficiency in selection for improved maternal ability, especially for weaning weight. Low maternal heritability estimates were also obtained by Mello et al. (2006), with estimates for birth weight and weaning weight equal to 0.03 and 0.04 , respectively. Santos et al. (2012) obtained estimates of direct and maternal heritability values for weaning weight of 0.33 and 0.16 , respectively, which are close to the results obtained in the present study. For weaning weight, Laureano et al. (2011), Silva et al. (2012) and Souza et al. (2011) obtained lower values than those found here: $0.23 ; 0.24$ and 0.14 , respectively. The estimate obtained in this study suggests that a considerable part of the variation in weight at this age among 
the animals results from the direct genetic effect.

Moderate-to-high heritability estimates for weaning and post-weaning weights, coupled with low maternal heritability estimate for weaning weight, indicate lower dependence of the offspring to obtain greater weights from the contribution of their dams, which demonstrates that most a considerable part of the total variability is due to additive genetic action. These results are verified by the negative correlation between additive genetic effect and maternal genetic effect at weaning. Similar results were found by Ribeiro et al. (2001).

Garneiro et al. (2010) estimated a heritability for year weight of 0.31 (same as that obtained in the present study) and 0.26 for yearling weigh (lower than that obtained here). Heritability estimates for year and yearling similar to those obtained in the current study were found by Gonçalves et al. (2011) and Silva et al. (2012). In contrast, Santos et al. (2012) obtained heritability estimates of 0.51 for year weight and 0.41 for yearling weight, which are higher values than those observed in this study.

The maternal additive heritability estimate for weaning weight $(0.05)$ was similar to that obtained by Silva et al. (2013), and indicates that the maternal effect had little importance on this weight, and consequently there would be difficulties in improving the maternal ability for this trait by selection, given the genetic antagonism between the direct and maternal effects (correlation of -0.68 ).

Overall, the direct heritability estimates for body weight at the different evaluated ages were of moderate magnitude, indicating that the additive genetic variabilities would be sufficient to provide responses to selection.

Table 2. Estimates of direct heritability $\left(h^{2} a\right)$ and maternal heritability $\left(h^{2} m\right)$ and correlation (r) between the additive genetic direct and maternal effects for birth weight (BW), and weaning (W210), year (W365) and yearling (W550) weights

\begin{tabular}{lcccc}
\hline \multirow{2}{*}{ Parameters } & \multicolumn{4}{c}{ Traits } \\
\cline { 2 - 5 } & $\mathrm{BW}$ & $\mathrm{W} 210$ & $\mathrm{~W} 365$ & $\mathrm{~W} 550$ \\
\hline $\mathrm{h}^{2} \mathrm{a}$ & $0.37 \pm 0.02$ & $0.36 \pm 0.03$ & $0.31 \pm 0.01$ & $0.38 \pm 0.01$ \\
$\mathrm{~h}^{2} \mathrm{~m}$ & $0.11 \pm 0.03$ & $0.05 \pm 0.01$ & - & - \\
$\mathrm{r}$ & -0.68 & -0.35 & - & - \\
\hline
\end{tabular}

Genetic correlations between birth weight and other weights were of low magnitude, ranging from 0.22 to 0.34 , indicating little influence of birth weight on the other ages. Higher estimates of genetic correlations between birth weight and the weights at other ages were found by Bolingon et al. (2009). Genetic correlation values observed in this study were close to those obtained by Yokko et al. (2007). Silva et al. (2013) found positive estimates of genetic correlation of average magnitude (0.55) between weaning and yearling weights; a high correlation (0.80) between weaning weight and year weight; and a correlation of 0.85 between year and yearling weights.

Additionally, genetic correlations between W210; W365 and W550 were all higher than 0.85 , indicating that heavier animals at weaning responded with greater weights at later ages. The 
greater correlations estimated in this study are associated with the period from weaning to yearling, indicating that the genes responsible for greater weights in this period are mostly the same. Thus, selection to increase weaning weight provides an increase in year and yearling weights.

Generating the expected progeny differences (EPD) for each selection criterion as well as composing the EPD for total maternal effect as half the direct EPD for weaning weight plus maternal EPD for the same weight, for the sires whose offspring were producing, it can be seen that they have mean and median close to zero for direct and maternal EPD for birth weight, are positive for weaning, year and yearling weights, and for the total maternal criterion. However, based on the amplitude observed for the EPD of weaning, year, and yearling weights, it was found that accurate selection criteria can provide an increase in these weights by the selection process performed on them.

Considering the selection of the tenpercent best sires based on the EPD of the total maternal effect, there is an increase in the predicted values for direct EPD at weaning, year, and yearling, with much more positive sires selected for each one of these criteria. There is also an increase in direct EPD for birth weight, but with a lower amplitude of the values, with minimum and maximum values closer to zero (Table 3).

Table 3. Means, standard deviations (SD), median, minimum and maximum values for breeding values predicted for all criterions of selections to the ten-percent best sires selected based on the total genetic maternal effect criterion

\begin{tabular}{lccccc}
\hline Prediction & Means & SD & Medians & Minimum & Maximum \\
\hline DEPD $_{\mathrm{BW}}$ & 0.28 & 0.58 & 0.29 & -1.54 & 1.09 \\
MEPD $_{\mathrm{BW}}$ & -0.10 & 0.22 & -0.09 & -0.43 & 0.59 \\
$\mathrm{DEPD}_{\mathrm{W} 210}$ & 7.43 & 2.43 & 7.58 & 1.47 & 12.08 \\
MEPD $_{\mathrm{W} 210}$ & -0.55 & 1.11 & -0.82 & -2.25 & 1.91 \\
DEPD $_{\mathrm{W} 365}$ & 6.68 & 3.87 & 6.40 & -1.22 & 15.76 \\
DEPD $_{\mathrm{W} 550}$ & 6.31 & 5.12 & 6.67 & -6.59 & 17.79 \\
DEPD $_{\mathrm{TM}}$ & 3.16 & 0.68 & 2.99 & 2.41 & 5.24 \\
\hline
\end{tabular}

$\mathrm{DEPD}_{\mathrm{BW}}=$ direct EPD for birth weight; $\mathrm{MEPD}_{\mathrm{BW}}=$ maternal EPD for birth weight; $\mathrm{DEPD}_{\mathrm{W} 210}=$ direct EPD for weaning weight; $\mathrm{MEPD}_{\mathrm{W} 210}=$ maternal EPD for weaning weight; $\mathrm{DEPD}_{\mathrm{W} 365}=$ direct EPD for year weight; $\mathrm{DEPD}_{\mathrm{W} 550}=$ direct $\mathrm{EPD}$ for yearling weight; and $\mathrm{DEPD}_{\mathrm{TM}}=$ direct $\mathrm{EPD}$ for total maternal effect.

Table 4 shows the rank correlations (Spearman correlations) among direct and maternal EPD at birth weight and weaning weight, in addition to direct EPD at year and yearling weights and total maternal effect for all sires with offspring in production and also the tenpercent best sires selected based on total maternal effect.
The present results confirm the antagonistic relationship between additive genetic effects for direct and maternal birth and weaning weights. Sires with higher EPD at weaning are not necessarily the largest holders of EPD for year weight and yearling weight, whereas the selection of bulls for year weight may coincide largely with the choice of the best sires for 
Rev. Bras. Saúde Prod. Anim., Salvador, v.15, n.4, p.846-853 out./dez., 2014 http://www.rbspa.ufba.br ISSN 15199940

yearling weight. The use of sires with higher EPD for the total maternal effect allows for the selection of sires with breeding values that are more positive for weaning weight as well as year and yearling weights.

Table 4. Rank correlations between expected progeny differences (EPD) of all sires with offspring in production (above the diagonal) and the ten-percent best sires (below the diagonal) selected based on total maternal effect

\begin{tabular}{lccccccc}
\hline Prediction & DEPD $_{\mathrm{BW}}$ & MEPD $_{\mathrm{BW}}$ & DEPD $_{\mathrm{W} 210}$ & MEPD $_{\mathrm{W} 210}$ & DEPD $_{\mathrm{W} 365}$ & DEPD $_{\mathrm{W} 550}$ & DEPD $_{\mathrm{TM}}$ \\
\hline $\mathrm{DEPD}_{\mathrm{BW}}$ & 1.00 & -0.86 & 0.06 & -0.07 & 0.29 & -0.11 & 0.07 \\
$\mathrm{MEPD}_{\mathrm{BW}}$ & -0.96 & 1.00 & 0.03 & -0.01 & -0.46 & -0.02 & -0.09 \\
$\mathrm{DEPD}_{\mathrm{W} 210}$ & 0.26 & -0.23 & 1.00 & -0.86 & 0.12 & 0.04 & 0.43 \\
$\mathrm{MEPD}_{\mathrm{W} 210}$ & -0.24 & 0.21 & -0.79 & 1.00 & -0.14 & -0.04 & 0.01 \\
$\mathrm{DEPD}_{\mathrm{W} 365}$ & 0.16 & -0.15 & 0.69 & -0.52 & 1.00 & 0.53 & -0.03 \\
$\mathrm{DEPD}_{\mathrm{W} 550}$ & 0.11 & -0.09 & 0.47 & -0.29 & 0.57 & 1.00 & -0.06 \\
DEPD $_{\mathrm{TM}}$ & 0.22 & -0.20 & 0.95 & -0.59 & 0.67 & 0.47 & 1.00 \\
\hline
\end{tabular}

$\mathrm{DEPD}_{\mathrm{BW}}=$ direct EPD for birth weight; $\mathrm{MEPD}_{\mathrm{BW}}=$ maternal EPD for birth weight; $\mathrm{DEPD}_{\mathrm{W} 210}=$ direct EPD for weaning weight; $\mathrm{MEPD}_{\mathrm{W} 210}=$ maternal $\mathrm{EPD}$ for weaning weight; $\mathrm{DEPD}_{\mathrm{W} 365}=$ direct EPD for year weight; $\mathrm{DEPD}_{\mathrm{W} 550}=$ direct $\mathrm{EPD}$ for yearling weight; and $\mathrm{DEPD}_{\mathrm{TM}}=$ direct $\mathrm{EPD}$ for total maternal effect.

Selection of sires based on growth traits from birth to yearling provides significant genetic gains in body weight in the Nellore breed, using information of the individual itself.

Selection of the best sires based on total maternal effect may benefit the selection of heavier animals at year and yearling.

\section{REFERENCES}

BOLIGON, A.A.; ALBUQUERQUE, L.G.; MERCADANTE, M.E.Z.; LÔBO, R.B. Study of relations among age at first calving, average weight gains and weights from weaning to maturity in Nellore cattle. Revista Brasileira de Zootecnia, v.39, p.746-751, 2010.

BOLINGON, A.A.; ALBUQUERQUE, L.G.; MERCADANTE, M.E.Z.; LÔBO, R.B.; Herdabilidades e correlações entre pesos do nascimento à idade adulta em rebanhos da raça Nelore. Brazilian
Journal of Animal Science, v.38, n.12, p.2320-2326, 2009.

DIAS, L.T.; ALBUQUERQUE, L.G.; TONHATI, H.; TEIXEIRA, R.A.

Estimação de parâmetros genéticos para peso em diferentes idades para animais da raça Tabapuã. Brazilian Journal of Animal Science, v.34, n.6, p.19141919, 2005.

GARNERO, A.V.; LÔBO. R.B.; BEZERRA, L.A.F.; OLIVEIRA, H.N. Comparação entre Alguns Critérios de Seleção para Crescimento na Raça Nelore. Brazilian Journal of Animal Science, v.30, n.3, p.714-718, 2010.

GONÇALVES, F.M; PIRES, A.V.; PEREIRA, I.G.; GARCIA, D.A.; FARAH, M.M.; MEIRA, C.T.; CRUZ, V.A.R. Avaliação genética para peso corporal em um rebanho Nelore.

Arquivo Brasileiro de Medicina Veterinária e Zootecnia, v.63, n.1, p.158-164, 2011. 
Rev. Bras. Saúde Prod. Anim., Salvador, v.15, n.4, p.846-853 out./dez., 2014 http://www.rbspa.ufba.br ISSN 15199940

LAUREANO, M.M.M.; BOLIGON, A.A.; COSTA, R.B.; FORNI, S.; SEVERO, J.L.P.; ALBUQUERQUE, L.G. Estimativas de herdabilidade e tendências genéticas para características de crescimento e reprodutivas em bovinos da raça Nelore. Arquivo Brasileiro de Medicina Veterinária e Zootecnia, v.63, n.1, p.143-152, 2011.

MELLO, S. de P.; ALENCAR, M.M. de; TORAL, F.L.B.; GIANLORENÇO, V.K. Estimativas de parâmetros genéticos para características de crescimento e produtividade em vacas da raça Canchim, utilizando-se inferência bayesiana. Brazilian Journal of Animal Science, v.35, n.1, p.92-7, 2006.

MEYER, K. WOMBAT - A program for mixed model Analyses by Restricted Maximum Likelihood. Journal of Zhejiang University Science B, v.8, n.11, p.815-821, 2007.

MUCARI, T.B.; OLIVEIRA, J.A. Análise genético-quantitativa de pesos aos $8,12,18$ e 24 meses de idade em um rebanho da raça Guzerá. Brazilian Journal of Animal Science, v.32, n.6, p.1604-1613, 2003.

RIBEIRO, M.N.; PIMENTA FILHO, E.C.; MARTINS, G.A. SARMENTO, J.L.R. MARTINS FILHO, R.

Herdabilidade para Efeitos Direto e Materno de Características de Crescimento de Bovinos Nelore no Estado da Paraíba. Brazilian Journal of Animal Science, v.30, n.4, p.12241227, 2001.

SANTOS, G.C.J.; LOPES, F.B.; MARQUES, E.G.; SILVA, M.C.; CAVALCANTE, T.V.; FERREIRA, J.L. Tendência genética para pesos padronizados aos 205,365 e 550 dias de idade de bovinos Nelore na região norte do Brasil. Acta Scientiarum Animal

Sciences, v.34, n.1, p.97-101, 2012.

SAS Institute. Statistical analysis system: user's guide: statistics. Cary, NC, 2010.

SILVA, J.A.V.; MARCELO, E.T.; RIBEIRO, C.B.; MAIORANO, A.M.; CURI, R.A.; OLIVEIRA, H.N.; MOTA, M.D.S. Análise genética de características de crescimento e perímetro escrotal em bovinos da raça Brangus. Pesquisa Agropecuária Brasileira, v.47, n.8, p.1166-1173, 2012.

SILVA, R.M.; SOUZA, J.C.; SILVA, L.O.C.; SILVEIRA, M.V.; FREITAS, J.A.; MARÇAL, M.F. Parâmetros e tendências genéticas para pesos de várias idades em bovinos Nelore.

Revista Brasileira de. Saúde e Produção. Animal [online], v.14, n.1, p.21-28, 2013

SOUZA, J.C.; SILVA, L.O.C.; GONDO, A.; FREITAS, J.A.; MALHADO, C.H.M.; FILHO, P.B.F.; SERENO, J.R.B.; WEABER, R.L.; LAMBERSON, W.R. Parâmetros e tendência genética de peso de bovinos criados à pasto no Brasil. Archivos de Zootecnia, v.60, n.231, p.457-465, 2011.

YOKOO, M.J.I.; ALBUQUERQUE, L.G.; LÔBO, R.B.; SAINZ, R.D.; CARNEIRO JÚNIOR, J.M.; BEZERRA, L.A.F.; ARAÚJO, F.R.C. Estimativas de parâmetros genéticos para altura do posterior, peso e circunferência escrotal em bovinos da raça Nelore. Brazilian Journal of Animal Science, v.36, n.6, p.17611768, 2007.

Data de recebimento: 27/02/2014

Data de aprovação: 25/11/2014 